\title{
CORRECTION
}

\section{Correction to: Whale shark (Rhincodon typus) predatory flexible feeding behaviors on schooling fish}

\author{
Austin N. Montero-Quintana' ${ }^{1}$ Carlos F. Ocampo-Valdez ${ }^{1}$ J. Abraham Vázquez-Haikin ${ }^{2}$. Oscar Sosa-Nishizaki ${ }^{3}$. \\ Marcela Osorio-Beristain ${ }^{1}$ (D)
}

Published online: 14 September 2021

(c) Japan Ethological Society 2021

\section{Correction to: Journal of Ethology (2021) 39:399-410 https://doi.org/10.1007/s10164-021-00717-y}

In the original publication of the article, the fourth author's last name published incorrectly. The correct name is given in this correction.

The original article has been corrected.

Publisher's Note Springer Nature remains neutral with regard to jurisdictional claims in published maps and institutional affiliations.

The original article can be found online at https://doi.org/10.1007/ s10164-021-00717-y.

Marcela Osorio-Beristain

mosorio@uaem.mx

1 Centro de Investigación en Biodiversidad y Conservación, Universidad Autónoma del Estado de Morelos, 62209 Cuernavaca, Morelos, Mexico

2 Grupo de Monitoreo Comunitario Pejesapo, Bahía de los Ángeles, Baja California, Mexico

3 Centro de Investigación Científica y de Educación Superior de Ensenada, Baja California, Mexico 